\title{
White Sandstone in Subathu Sub-Basin: an example of tectonically driven forced regressive wedge
}

\author{
MK Bera ${ }^{1 *}$, A Sarkar ${ }^{1}$ and PP Chakraborty ${ }^{2}$ \\ 1 Department of Geology and Geophysics, Indian Institute of Technology, Kharagpur-721302, INDIA \\ 2 Department of Applied Geology, Indian School of Mines, Dhanbad 826 004, INDIA \\ * Corresponding author: e-mail:melinda_bera@yahoo.com
}

Sediments of the Himalayan peripheral foreland basin, developed due to progressive thrust-loading (DeCelles and Giles 1996, Dickinson 1974) and subsequent exhumation/upliftment of the mountain chain, records signature of hinterland tectonics visa-vis basin filling processes. The synchroneity of the foreland sediments with widespread early Oligocene glaciation suggests that hypothesis of tectonics-climate connection, whereby the cooling was driven by drop in atmospheric $\mathrm{CO}_{2}$ via enhanced silicate weathering of the rising Himalayan orogen (Raymo and Ruddiman 1992, Pagani et al. 2005), has considerable merit. As a test-case Paleogene Sub-Himalayan foreland sediments of marine Subathu and continental Dagshai formation rocks were studied to identify the teleconnection between tectonics and climate, if any. The Subathu-Dagshai transition here is marked by the presence of a $\sim 31 \mathrm{Ma}$ old (Najman et al. 2004) characteristic quartz rich mature sandstone locally termed as the "White Sandstone". It marks the termination of marine Subathu Formation and initiation of continental molasses Dagshai Formation and represents an important evolutionary stage in the geodynamic history of the foreland basin (DeCelles and Giles 1996, Sinclair 1997). However, the status of White Sandstone has always been uncertain varying between marine Subathu (a beach or tidal flat; Singh and Khanna 1980, Srivastava and Casshyap 1983) to fluvial Dagshai (Najman et al. 2000, 2004). Further, raging debates exist about the possible continuity/discontinuity between Subathu and Dagshai formations (see Bera et al. 2008 and references therein). Since the White Sandstone plays a crucial role in this debate the present study focused on process based sedimentology of this unit. Detailed bed form geometry and sedimentary structure shows that the White Sandstone unit is made up of three distinct components viz., Lower shoreface (between fair weather wave base and storm wave base), Upper shoreface (above fair weather wave base) and Foreshore/beach. Lower shoreface deposits are characterized by intercalation of centimeter thick fine sand and shale couplets, although definite signature of hummocky cross stratified (HCS) unit is not recorded in the present study. These units lie between two erosional surfaces. The lower erosional surface is sharp and it places the units directly over the offshore/ shelf sediments. Presence of gutter cast and rip-up clast at the base of these units suggest the lower erosional surface must be a storm weather wave base or regressive surface of marine erosion (RSME) (Plint 1988). The upper erosional surface is marked by the truncation of the fine sand shale intercalation of lower shoreface with decimeter thick lenticular unit of upper shoreface and dips towards the basinal depocenter. The presence of this surface above basal RSME allowed us to interpret it as a fair weather wave base or "surf diastem" (of Swift et al. 2003). Recent studies (Fraser et al. 2005, Tamura et al. 2007) show that this fair wave base is an important component of shoreface sand deposits, as it helps in assessing the change in progradation of the upper shoreface deposits during forced regression. Our study shows that the basal RSME is not a single erosional surface developed due to fall in storm wave base; at places, where lower shoreface is absent, fair weather wave base amalgamates with it. The amalgamation depends upon the preservation of lower shoreface which, in turn, governed by both sediment supply and rate of sea level fall during forced regression. As mentioned earlier, the upper shoreface deposits are characterized by the decimeter thick lenticular sandy units. The meter thick thinning and finning upward nature of these lenticular beds and internal truncation of these bed sets suggest its probable longshore bar origin (Tamura et al. 2007). The presence of wave ripples on top of the beds and foreshore/beach deposits above it indicate its upper shoreface environment. The foreshore/beach deposits are characterized by decimeter thick parallel bed sets with very low angle cross stratification and sometimes show parting lineation. This unit is overlain by either interfluve sediments with extensive caliche development or cut by Dagshai channel sandstone. The presence of basal RSME and fluvial incision and/or caliche development on the top of white sandstone unit indicate it as a product (an FSST wedge) of forced regression (Hunt and Tucker 1992, Catuneanu 2002). Our spatially extensive new petrographic dataset suggest a sudden increase in metamorphic detritus from the White Sandstone unit onwards indicating initiation of exhumation of the Himalayan metamorphic core during this time. Our study has three important implications. First, the $\sim 31 \mathrm{Ma}$ white sandstone is marine not fluvial and hence the unconformity occurs above it not below. Second, the forced regression was possibly tectonically driven due to sudden hinterland uplift. Third, the timing of this tectonically driven forced regression coincides with the rapid rise in sea water $\mathrm{Sr}$ isotope ratio (from 0.7077 to 0.708 ) further strengthening the hypothesis that uplift driven silicate shedding might have causal link with the early Oligocene cooling.

\section{References}

Bera MK, A Sarkar, PP Chakraborty, RS Loyal and P Sanyal. 2008. Marine to continental transition in Himalayan foreland. Geological Society of America Bulletin. (In press).

Catuneanu O. 2002. Sequence stratigraphy of clastic systems: Concepts, merits, and pitfalls. Journal of African Earth Sciences 35: 1-43

DeCelles PG and KA Giles. 1996. Foreland basin systems. Basin Research 8: $105-123$ 
Dickinson WR. 1985. Interpreting provenance relations from detrital modes of sandstones. In: Zuffa GG (eds) Provenance of arenites: Dordrecht, NATO ASI series C, 148, D. Reidel p333-361

Fraser C, PR Hill and M Allard. 2005. Morphology and facies architecture of a falling sea level strandplain, Umiujaq, Hudson Bay, Canada. Sedimentology 52: 141-160

Hunt D. and ME Tucker. 1992. Stranded parasequences and the forced regressive wedge systems tract: Deposition during base level fall. Sedimentary Geology 81: 1-9

Najman Y, M Bickle and H Chapman. 2000. Early Himalayan exhumation: Isotopic constraints from the Indian foreland basin. Terra Nova 12: 28-34

Najman Y, K Johnson, N White and G Oliver. 2004. Evolution of Himalayan foreland basin, NW India. Basin Research 16: 1-24

Pagani M, JC Zachos, KH Freeman, B Tripple and S Bohaty. 2005. Marked decline in atmosphere carbon dioxide concentrations during the Paleogene. Science 309: 600-603

Plint AG. 1988. Sharp-based shoreface sequences and 'offshore bars' in the Cardium Formation of Alberta: Their relationship to relative changes in sea level. In: Wilgus CK, BS Hastings CGStC Kendall, HW Posamentier, CA Ross and JC Van Wagoner (eds), Sealevel
changes-An integrated approach. SEPM (Society for Sedimentary Geology) Special Publication 42: 357-370

Raymo ME and WF Ruddiman. 1992. Tectonic forcing of late Cenozoic climate. Nature 359: 117-122

Sinclair HD. 1997. Tectonostratigraphic model for underfilled peripheral foreland basins: An Alpine perspective. Geological Society of America Bulletin 109: 324-346

Singh HP and AK Khanna. 1980. Palynology of the Paleogene marginal sediments of Himachal Pradesh, India. Lucknow. Proceedings Fourth International Palynological Conference 1: 462-471

Srivastava VK and SM Casshyap. 1983. Evolution of the pre-Siwalik Tertiary basins of Himachal Himalaya. Journal of Geological Society of India 24: 134-147

Tamura T, F Nanayama, Y Saito, F Murakami, R Nakashima and K Watanabe. 2007. Intra-shoreface erosion in response to rapid sealevel fall: depositional record of a tectonically uplifted strand plain, Pacific coast of Japan. Sedimentology 54: 1149-1162

Swift DJP, BS Parsons, A Foyle and GF Oertel. 2003. Between beds and sequences: stratigraphic organization at intermediate scale in the Quarternery of the Virginia coast, USA. Sedimentology 50: 81-111 